Available online on 15.09 .2020 at http://jddtonline.info
Open Access to Pharmaceutical and Medical Research
unrestricted non-commercial use, provided the original work is properly cited

Open $\odot$ Access

Research Article

\title{
In vivo and in vitro antioxidant and anti-hemolytic effect of Algerian Centaurea calcitrapa L. extracts
}

\author{
Trabsa Hayat ${ }^{*}, a, b$, Baghiani Abderrahmana, Boussoualim Naouela, Krache Imanea and Arrar Lekhmicia \\ a Laboratory of Applied Biochemistry; Department of biochemistry Faculty of natural and life sciences, University Ferhat Abbas of Setif, Algeria \\ b Faculty of Exact Sciences and Nature and Life Sciences, Department of Nature and Life Sciences, University of Biskra, Algeria
}

\begin{abstract}
In the present study, aerial part of Centaurea calcitrapa L. were extracted with solvent of varying polarity allowed their separation into three main subfractions, the analysis of methanol crud $(\mathrm{CrE})$, chloroform (ChE) and ethyl acetate (EaE) extracts, showed that the EaE contains the highest amount of flavonoids (50,71 $\pm 0,65 \mathrm{mg} \mathrm{Eq} /$ Quercetin g dry extract and 31,96 $\pm 0,39 \mathrm{mg}$ Eq Rutin / g dry extract). Using DPPH assay, the highest activity was observed with $\mathrm{EaE}\left(\mathrm{IC}_{50}=0,037 \pm 0,0006 \mathrm{mg} / \mathrm{ml}\right)$. The $\beta$-carotene / linoleic acid bleaching assay revealed that the extracts have a very important antioxidant activity. The results showed that $\mathrm{CrE}$ has the highest antioxidant activity. The antioxidant activity of the $\mathrm{CrE}$ is confirmed by an in vivo assay in mice, using two doses: $\mathrm{CrD}_{1}(50 \mathrm{mg} / \mathrm{kg} / \mathrm{day})$ and $\mathrm{CrD}_{2}(100 \mathrm{mg} / \mathrm{kg} / \mathrm{day})$ during 21 days. Total antioxidant capacity of plasma and red blood cells was measured. The half-life ( $\left.\mathrm{HT}_{50}\right)$, which corresponds to $50 \%$ of cell lysis was calculated, the results showed that both groups treated with plant extract had a protective effect against erythrocytes hemolysis $\left(\mathrm{CrD}_{2}: \mathrm{HT}_{50}=167,3 \pm 3,72 \mathrm{~min}\right)$. The $\mathrm{CrD}_{2}$ group showed a strong scavenging activity using DPPH assay (51,64 $\left.\pm 5,24 \%\right)$, higher than that of Vit C group (38,92 $\left.\pm 1,72 \%\right)$. All results confirmed that the extracts have a dose dependent effect on the growth of overall antioxidant defenses. These results support the use of this plant against anti-inflammatory diseases in traditional medicine.
\end{abstract}

Keywords: Centaurea calcitrapa L., in vivo-antioxidant activity, DPPH, hemolysis, flavonoids.

Article Info: Received 18 July 2020; Review Completed 25 Aug 2020; Accepted 03 Sep 2020; Available online 15 Sep 2020

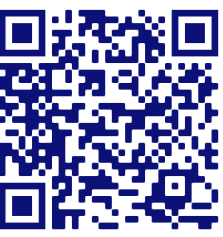

Cite this article as:

Trabsa H, Baghiani A, Boussoualim N, Krache I, Arrar L, In vivo and in vitro antioxidant and anti-hemolytic effect of Algerian Centaurea calcitrapa L. extracts, Journal of Drug Delivery and Therapeutics. 2020; 10(5):202-207 http://dx.doi.org/10.22270/jddt.v10i5.4402

Trabsa hayat, Faculty of Exact Sciences and Nature and Life Sciences, Department of Nature and Life Sciences, University of Biskra, Algeria

\section{INTRODUCTION}

In recent studies, it has been repeatedly asserted that oxidative stress is correlated with over 100 diseases, it was defined as the lack of balance between the occurrence of reactive species (free radicals) and the organism's capacity to counteract their action by the antioxidative protection systems ${ }^{1}$. Free radicals are small, diffusible molecules that differ from most biological molecules in that they have an unpaired electron ${ }^{2}$. Free radicals generated in aerobic metabolism are involved in a series of regulatory processes. When generated in excess, free radicals can counteract the defense capability of the antioxidant system, impairing the essential biomolecules in the cell by oxidizing membrane lipids, cell proteins, carbohydrates, DNA, and enzymes ${ }^{3}$.

An antioxidant is defined as a molecule capable of slowing or preventing the oxidation of other molecules, whereas a biological antioxidant has been defined as; any substance that, when present at low concentrations compared to those of an oxidizable substrate, significantly delays or prevents oxidation of that substrate 4 .

Use of medicinal plants to treat common ailments has been prevalent since ancient times and different parts of the plants were used for public health. The use of natural treatments is cost-effective. Since ancient times, plants have been important in reducing pain and today the focus is on their role and ability in healing and their treatment properties for various diseases 5 .

The diversity of natural compounds in herbs and their different functions in preventing and treating different diseases on the one hand and their property of being natural and comfortable with the body and not having adverse effects providing their proper usage induces people toward their consumption; educated public and health care professionals have enormous interests concentrating studies on these herbs and diagnosing their therapeutic properties ${ }^{6}$.

Recently, research on natural antioxidants has become increasingly active in various fields. Accordingly, numerous 
articles on natural antioxidants, including polyphenols, flavonoids, vitamins, and volatile chemicals, have been published. Assays developed to evaluate the antioxidant activity of plants.

The genus Centaurea comprises 300-350 species. Several species have been applied in traditional medicine, however, the rationale of their application has been analyzed only in few studies ${ }^{7}$. Centaurea calcitrapa, a plant widely distributed in Hungary ${ }^{7}$, Portugal ${ }^{8}$, Italy ${ }^{9}$ and Algeria ${ }^{10}$. C. calcitrapa may be used, in a similar way to make artisanal cheese, a traditional dairy product ${ }^{7}$. Its healing properties have been

\section{MATERIALS AND METHODS}

Centaurea calcitrapa L. was collected from N'Gaous, Algeria in Mai 2015 and identified by Pr. Oudjehih B. (Institut of nutrition and agronomy, university of Batna, Algeria). A voucher specimen ( $\mathrm{N}^{\circ}$ : I.A.B./993) was kept in the herbarium of the same department for future reference. All other reagents were purchased from Sigma Chemicals (Germany), Fluka and Prolab.

Adult male mice (weighting 25 - 30 g) were purchased from the Pasteur Institute of Algeria and were kept under standardized conditions $\left(21-24{ }^{\circ} \mathrm{C}\right.$ and a $12 \mathrm{~h}$ light/dark cycle) and fed a normal laboratory diet. The animal experiments were performed in accordance with international guidelines for the use and care of laboratory animals ${ }^{11}$. Ethical approval for the animal experimentation was obtained from Ethics Review Committee of Faculty of Exact Sciences and Nature and Life Sciences, University of Biskra, Biskra, Algeria (approval ref no. 307/V.D.P.G.). The animals were transferred to the laboratory at least 1 week before the experiments.

\section{Flavonoids extraction}

The extractions were carried out using the powdered plant material (100 g), the powder was extracted with methanol, at room temperature for overnight. CrE was successively extracted with different solvents of increasing polarity: hexane for defatting, chloroform for aglycone flavonoids extraction and ethyl acetate for glycoside flavonoids extraction, each fraction was evaporated to dryness under reduced pressure to give methanol (CrE), chloroform (ChE) and ethyl acetate (EaE) extracts ${ }^{12}$.

\section{Determination of total flavonoid contents}

The total flavonoid content of each extract was determined by a colorimetric method ${ }^{13}$. Each sample $(1 \mathrm{ml})$ was mixed with $1 \mathrm{ml}$ of aluminum chloride $\left(\mathrm{AlCl}_{3}\right)$ solution $(2 \%)$ and allowed to stand for $15 \mathrm{~min}$. Absorbance of the mixture was then determined at $430 \mathrm{~nm}$ versus prepared methanol blank. Results were expressed as equivalent quercetin and rutin (mg quercetin or rutin /g dried extract).

\section{In vitro antioxidant activity}

\section{DPPH radical scavenging activity}

The stable free radical scavenging activity was determined bythe1,1-diphenyl-2-picryl-hydracyl (DPPH) method14. Fifty microliters of various concentrations of the samples in methanol were added to $1250 \mu \mathrm{l}$ of a $0.004 \%$ methanol solution of DPPH. After a 30 min incubation period at room temperature, the absorbance was read against a blank at 517 $\mathrm{nm}$. Inhibition of DPPH free radical in percent (I\%) was calculated in the following way:

$$
I \%=\frac{A_{c}-A_{e}}{A_{c}} X 100
$$

known since ancient times in the traditional medicine of different nations; antipyretic, digestive, for constipation and diarrhea ${ }^{9}$

In current work, we investigated reducing antioxidant potential and flavonoids contents of plant sample. To the best of our knowledge this plant has not been investigated for these features. We evaluated two in vitro methods; DPPH and $\beta$-carotene techniques for determining the antioxidant potential. Finally, an in vivo model was successfully used for analyzing total antioxidant capacity of plasma and red blood cells of methanolic extract of the plant.

Where $A_{c}$ is the absorbance of the control reaction (containing all reagents except the test compound), and $A_{e}$ is the absorbance of the test compound (in the presence of extracts). Sample concentration providing 50\% inhibition (IC50) was calculated from the graph plotting inhibition percentage against extract concentration. Tests were carried out in triplicate.

\section{Beta-carotene bleaching test}

The antioxidant capacity was determined by measuring the inhibition of $C$. calcitrapa extracts compounds and the conjugated diene hydroperoxides arising from linoleic acid oxidation ${ }^{15}$. Briefly, oxygenated water was mixed with bcarotene, Tween- 40 and linoleic acid. The mixture was incubated with or without $250 \mu \mathrm{l}$ of each extract $(2 \mathrm{mg} / \mathrm{ml})$, the emulsion system was incubated up to $48 \mathrm{~h}$ in dark at room temperature and the absorbance was read at $490 \mathrm{~nm}$. Antioxidant activity (AA\%) was calculated using the equation:

$$
A A \%=\frac{A_{e}}{A_{c}} X 100
$$

Where $A_{c}$ : control absorbance (BHT), and $A_{e}$ : absorbance in the presence of extracts.

\section{In vivo antioxidant activity}

Adult male mice were divided into four groups of 8-9 animals, the extract was dissolved in normal saline. Groups 1 and 2 received $\mathrm{CrE}$ dose $1\left(\mathrm{GCrD}_{1}: 50 \mathrm{mg} / \mathrm{kg} /\right.$ day), $\mathrm{CrE}$ dose 2 (GCrD $2: 100 \mathrm{mg} / \mathrm{kg} /$ day) expressed as $\mathrm{mg}$ dry extract per $\mathrm{kg}$ body mass, via intra-peritoneal injection for 21 days. The $3^{\text {rd }}$ group or native control received only saline (GT) and the 4 rd group was treated with vitamin C (GVit C: $50 \mathrm{mg} / \mathrm{kg} /$ day). In the $21^{\text {th }}$ day, about $1 \mathrm{~mL}$ of blood was collected through direct heart puncture from anesthetized mice. An aliquot of $100 \mu \mathrm{l}$ of whole blood is immediately transferred to tube containing $2.4 \mathrm{ml}$ of phosphate buffer ( $300 \mathrm{mOsm}$; , pH 7.4) to obtain a dilution of 1:25 (v:v). The rest of blood was centrifuged at $2000 \times \mathrm{g}$ for 10 minutes to separate plasma. The plasma was kept at $-20^{\circ} \mathrm{C}$ for subsequent determination of antioxidant status.

\section{Total antioxidant capacity of plasma and red blood cells}

Resistance to free radical damage was tested and measured as the capacity of red blood cells (RBCs) to withstand free radical induced hemolysis 17 , with slight modifications. Briefly, the mice's blood diluted 1:25, then $50 \mu \mathrm{L}$ of RBC suspension or whole blood were assayed using a 96-well microplate coated with a $t$ - $\mathrm{BH}$ as a free radical generator. The kinetics of RBC resistance to hemolysis was determined at $37^{\circ} \mathrm{C}$ by continuous monitoring of changes in $630-\mathrm{nm}$ absorbance. The time to reach $50 \%$ of total hemolysis $\left(\mathrm{HT}_{50}\right)$ was retained, and hemolysis inhibition (HI): (HT50 sample$\mathrm{HT}_{50}$ temoin)/HT $\mathrm{H}_{50}$ temoin. 


\section{DPPH radical scavenging activity of serum}

In this test, the serum ability to inhibit DPPH radical was measured 18 , DPPH is one of the few stable organic nitrogen radicals and has a maximum absorption at $517 \mathrm{~nm} .25 \mu \mathrm{L}$ of mice's serum was added to $625 \mu \mathrm{L}$ of DPPH solution ( $4 \mathrm{mg} /$ $100 \mathrm{ml}$ methanol) and the reaction mixture was shaken vigorously. After incubation at room temperature for $30 \mathrm{~min}$, the absorbance of the solution was determined at $517 \mathrm{~nm}$. The results were compared with the DPPH solutions in the absence of the serum.

\section{Statistical Analysis}

The results are expressed as mean \pm SD or SEM. Where applicable, the data were subjected to one-way analysis of variance (ANOVA), where the differences between extracts were determined by Tukey's multiple comparison test, Dunnett's and multiple comparison test for comparison between extracts and standards, using GraphPad program. $P$ $\leq 0.05$ was regarded as significant.

\section{RESULTS AND DISCUSSION}

\section{Determination of total flavonoid contents}

Flavonoids as one of the most diverse and widespread group of natural compounds are probably the most important natural phenolics. There has been increasing interest in the research on flavonoids from plant sources because of their versatile health benefits reported in various epidemiological studies. These compounds possess a broad spectrum of chemical and biological activities including radical scavenging properties ${ }^{19}$.

The flavonoids content of $C$. calcitrapa was estimated using $\mathrm{AlCl}_{3}$ method, and calculated as mg QE and RE/g of extract. According to the results shown in Table 1, the content of flavonoids decrease in the order: $\mathrm{EAE}, \mathrm{ChE}$ and $\mathrm{CrE}$.

Table 1: Flavonoids content of $C$. calcitrapa extracts.

\begin{tabular}{clc}
\hline Extracts & \multicolumn{2}{c}{ Flavonoids content } \\
\cline { 2 - 3 } & mg QE/g extract & mg RE/g extract \\
\hline EAE & $50,71 \pm 0,65$ & $31,96 \pm 0,39$ \\
\hline ChE & $30,96 \pm 0,55$ & $19,38 \pm 0,33$ \\
\hline CrE & $27,29 \pm 0,18$ & $17,16 \pm 0,11$ \\
\hline
\end{tabular}

Denni and mammen (2012) showed that any blockage of the hydroxyl groups by glycosylation in carbons of positions 3,5 , $3^{\prime}$ or 4' prevents chelation with $\mathrm{AlCl}_{3}{ }^{20}$. Which explains, in our studie, the strong reactivity of quercetrin with $\mathrm{AlCl}_{3}$ compared to rutin (quercetin-3-0-rutinosid).

\section{In vitro antioxidant activity}

\section{DPPH radical scavenging activity}

The DPPH radical scavenging method is a standard procedure applied to evaluate the general antioxidant activity of plant extracts, especially which assigned to phenolic compounds, i.e. phenolic acids and flavonoids. DPPH radical scavenging activity of extracts increased with concentration (Figure 1).

DPPH assay was an easy and accurate method with regard to measuring the antioxidant capacity. However, the method has its limitations, particularly since the N-radical portion at the center of the DPPH structure is more accessible only to small molecules. Larger molecules may have limited access due to steric hindrances. Small molecules that have better contact with the N-radical centre site show higher antioxidant activity 21 .

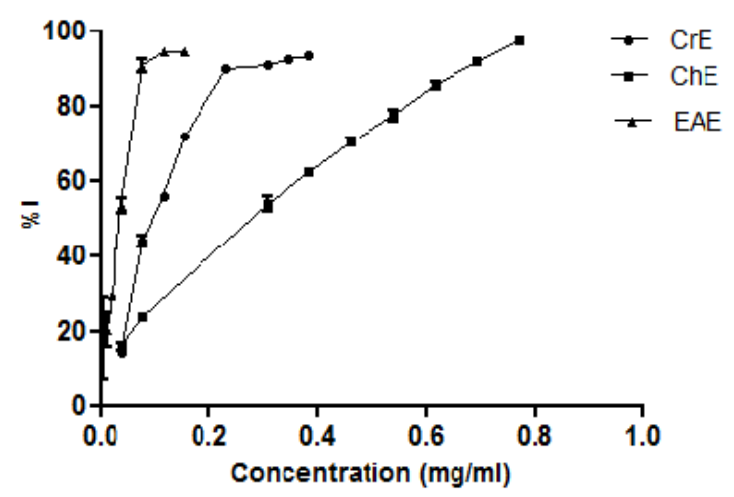

Figure 1: DPPH scavenging activity of $C$. calcitrapa extracts. Values were expressed as the mean \pm SD of triplicate.

The EAE was found to exhibit the greatest scavenger activity with $\mathrm{IC}_{50}$ of $(0.037 \pm 0,0006 \mathrm{mg} / \mathrm{ml})$, which is has the same activity of butylated hydroxytoluene (BHT: 0,032 $\pm 0,0186$ $\mathrm{mg} / \mathrm{ml}$ ), followed by $\mathrm{CrE}$ and $\mathrm{ChE}$ (Table 2). BHT is a most commonly used antioxidant recognized as safe for use in foods containing fats, pharmaceuticals, petroleum products, rubber and oil industries ${ }^{22}$. The results showed that quercitin have a stronger scavenger activity compared to rutin, this decrease in activity of rutin may be caused by the blockage of the hydroxyl groups by glycosylation (Rutinose) in carbons of positions 3 .

Table 2: DPPH scavenging activity of $C$. calcitrapa extracts and standards.

\begin{tabular}{cccc}
\hline Standards & IC $_{\mathbf{5 0}}(\mathbf{m g} / \mathbf{m l})$ & Extracts & IC $_{\mathbf{5 0}}(\mathbf{m g} / \mathbf{m l})$ \\
\hline BHT & $0,032 \pm 0,018$ & CrE & $0,109 \pm 0,001$ \\
\hline Gallic acid & $1.267 \pm 0.001^{\#}$ & ChE & $0,290 \pm 0,005$ \\
\hline Quercetin & $2.565 \pm 0.000^{\#}$ & EAE & $0,037 \pm 0,006$ \\
\hline Rutin & $5,586 \pm 0.000^{\#}$ & Vit C & $5,103 \pm 0,021^{\#}$ \\
\hline & $\#: \mu \mathrm{g} / \mathrm{ml}$.
\end{tabular}

Boumerfeg and their collaborators (2011), reported that the radical scavenging activity of plant extracts depends on the amount of polyphenolic compounds in the extracts. The extract, which had a strong antioxidant activity, contain high flavonoid contents ${ }^{23}$. However, in our study, the order of decreasing scavenging activity among the $C$. calcitrapa extracts was found to be $\mathrm{EAE}>\mathrm{CrE}>\mathrm{ChE}$, which is not in accordance with the amount of phenolic compounds present in these extracts. Also steric accessibility of an antioxidant compound, to the $\mathrm{N}$-radical portion at the center of the DPPH, can determine the type of reaction mechanism. EAE exhibit the highest activity, this activity could be attributed to its highest contents of phenols compounds as well as to the compound's nature (glycosidic polyphenols).

In recent years, the antioxidant activity of plant polysaccharide has become a hot spot in the field of polysaccharide research. Which has the functions of 
increasing antioxidant enzyme activity, eliminating free radicals, inhibiting lipid peroxidation and anti-oxidation ${ }^{24}$.

\section{Beta-carotene bleaching test}

Peroxidation of fatty acid chains is the basic cause of rancidity in fats and oils, and can occur in biological cells during oxidative stress. Indeed, breakdown products of fatty acid peroxides are often used as oxidative stress markers 25 .

Beta-carotene bleaching method is widely used to measure antioxidant activity of plant extracts. It is an in vitro assay that measures the inhibition of coupled auto-oxidation of linoleic acid and b-carotene. This method is based on the fact that lipid radicals as auto-oxidation products of linoleic acid attack double bonds of $\beta$-carotene, but the presence of an antioxidative substance can prevent the attack and retain the yellowish-orange colour of $\beta$-carotene and thus reduce their bleaching activity 26 .

All C. calcitrapa extracts reduced b-carotene bleaching by at least $70 \%$ (Figure 2), while EAE, CrE and ChE inhibited $\beta$ carotene bleaching by $84,32 \pm 2,07 \%, 84,05 \pm 4,99 \%$ and $78,48 \pm 0,34 \%$, respectively. The EAE present the highest contents, and nature (glycosidic) of polyphenoland the highest antioxidant activity, which was near to that of BHT $(96.32 \pm 0.99 \%)$ used as positive control. The present study found no direct correlation between phenol levels and $\beta$ carotene bleaching inhibition

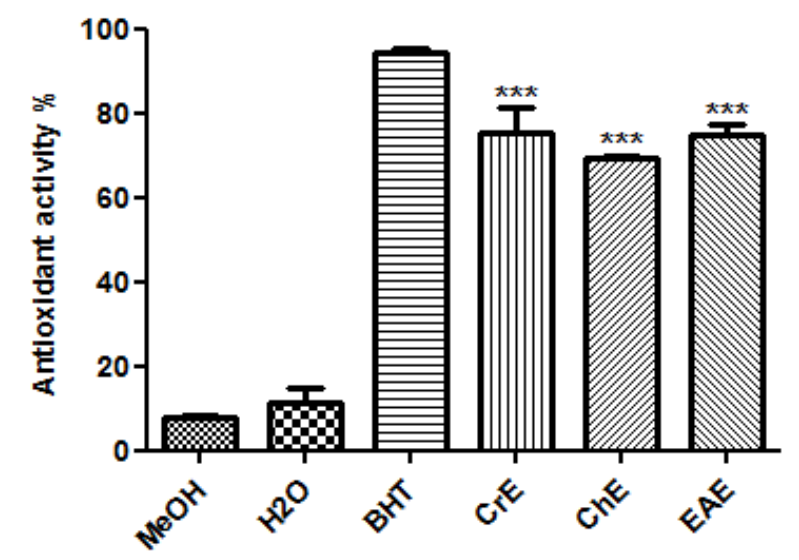

Figure 2: Antioxidant activity of C. calcitrapa extracts compared with BHT, methanol and water. Comparison was realized against positive control (BHT);**: $p \leq 0.001$.

\section{In vivo antioxidant activity}

\section{Total antioxidant capacity of plasma and red blood cells}

The capacity of flavonoids to act as antioxidants in vitro has been the subject of several studies in the past years, and important structure-activity relationships of the antioxidant activity have been established. The antioxidant efficacy of flavonoids in vivo is less documented, presumably because of the limited knowledge on their uptake in humans. During absorption of across the intestinal membrane, flavonoids are partly transformed in their conjugates. However, the major part of ingested flavonoids is not absorbed and is largely degraded by the intestinal microflora ${ }^{27}$. For that reason intra-peritoneal injection was used.

In the case of the group received only saline (GT), halfhemolysis $\left(\mathrm{HT}_{50}\right)$ was reached at about $140 \mathrm{~min}$ after $t$-BH addition, whereas under Vit $\mathrm{C}$ no hemolysis occurred during at least $160 \mathrm{~min}$ (Figure 3). The $\mathrm{CrD}_{2}$ showed the most effective inhibition capacity compared to the antioxidant reference (Vit C).

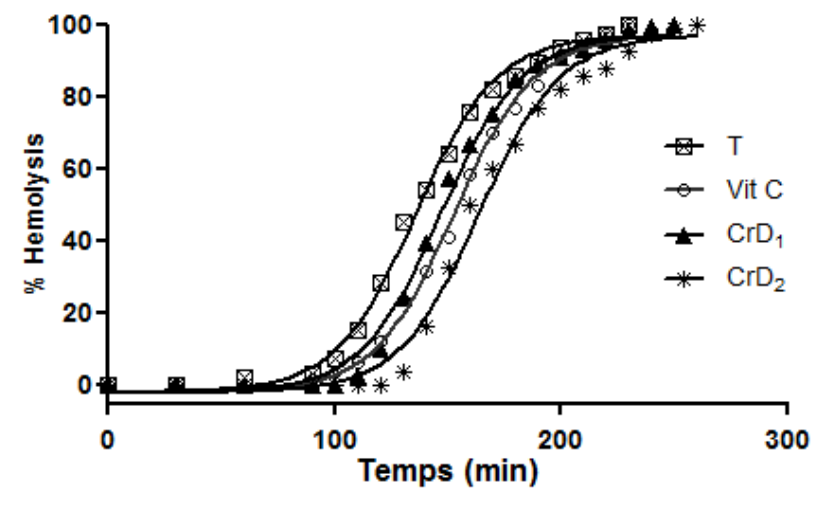

Figure 3: Hemolysis curve of fresh mice blood, in the presence of $t$-BHP for different groups, diluted in phosphate buffer ( $\mathrm{pH} 7.4$ ) in isotonic conditions from optical density reading.

Hemolysis, or the abnormal breakdown of circulating red blood cells (RBCs), is a major clinical problem that can be a disease process unto itself, or manifest as a component of another disorder. Because of the critical role that the lab plays in assessment of hemolytic disorders, and because there are a very wide variety of assays available for hemolysis ${ }^{28}$.

Exposure of red cells to t-butyl hydroperoxide resulted in crosslinking of hemoglobin subunits and probable crosslinking of cytoskeletal proteinsas suggested by the diminution in intensity of theprotein bands and the parallel increase in high molecular weight material. Membrane glycoproteins were not crosslinked. Cytoplasmic and membrane protein changes were not dependent on $t$-butyl hydroperoxide-induced lipid peroxidation ${ }^{29}$.

Hemolysis inhibition was noticed for thethree groups (Vit C, $\mathrm{CrD}_{1}$ and $\mathrm{CrD}_{2}$ ), from the kinetics of hemolysis obtained, the $\mathrm{D}_{1}$ group mice treated with methanol extract (50 mg / $\mathrm{kg}$ ), the increase in $\mathrm{HT}_{50}\left(\mathrm{HT}_{50}=156,5 \pm 5,31 \mathrm{~min}\right)$ is not statistically significant compared with the control group $\left(\mathrm{HT}_{50}=147,7 \pm 0,40 \mathrm{~min}\right)$. The administration of higher doses of methanol extract $\left(100 \mathrm{mg} / \mathrm{kg}\right.$ ) in mice group $\mathrm{D}_{2}$ caused a delay of hemolysis ( $\left.\mathrm{HT}_{50}=167,3 \pm 3,72 \mathrm{~min}\right)(\mathrm{p}>$ 0.05 ), which confirmed that the extracts have a dose dependent effect on the growth of overall antioxidant defenses (Figure 4). The mice's group treated with vitamin C $(100 \mathrm{mg} / \mathrm{kg})$ didn't significantly increase the $\mathrm{HT}_{50}$.

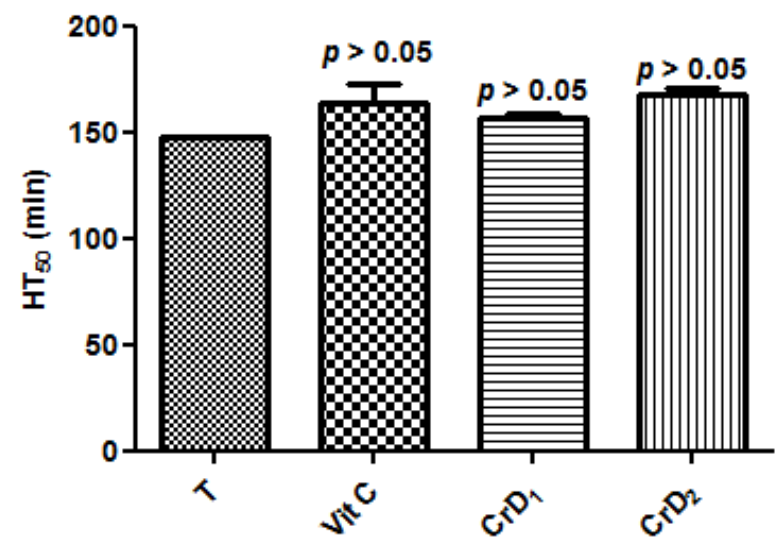

Figure 4: The half-life $\left(\mathrm{HT}_{50}\right)$ for the different groups. Values are means \pm SEM $(n=8-9)$. Comparisons are made with respect to the temoin group (control group treated with normal saline), Vit C (groups treated with a solution of Vit $\mathrm{C}$ $100 \mathrm{mg} / \mathrm{kg}$ ) $\mathrm{D}_{1}, \mathrm{D}_{2}$ (groups treated with CrE 50 and 100 $\mathrm{mg} / \mathrm{kg}$, respectively). 
The $\mathrm{CrD}_{2}$ showed the most effective inhibition capacity, higher than that of Vit $\mathrm{C}$ (Table 3). The results showed that both groups treated with plant extract had a protective effect against erythrocytes hemolysis comparable to GVitC and largely higher than the native control.

Table 3: Percentage of hemolysis inhibition

\begin{tabular}{cc}
\hline Groups & Hemolysis inhibition (\%) \\
\hline Vit C & $10,62 \pm 0,86$ \\
\hline CrD $_{1}$ & $5,95 \pm 0,32$ \\
\hline CrD $_{2}$ & $13,27 \pm 0,67$ \\
\hline
\end{tabular}

\section{DPPH radical scavenging activity}

The results showed that all the doses for C. calcitrapa extracts $\mathrm{CrD}_{1}(45,95 \pm 4,26 \%, 51,64 \pm 5,24 \%)$ and VitC $(38,92 \pm 1,72 \%)$ improved the serum DPPH scavenging potential (Figure 5).

The antioxidative potential of samples can be assayed by different in vitro and in vivo methods. Several antioxidants of plant origin are experimentally proved and used as effective protective agents against oxidative stress ${ }^{30}$. Vit C present a very strong activity in vitro (Table 2), compared to the $\mathrm{CrE}$, but the intra-peritoneal administration of Vit $\mathrm{C}$ and $\mathrm{CrE}$ showed that the $\mathrm{CrE}$ decrease the capacity of plasma better than the Vit C at the same dose $(50 \mathrm{mg} / \mathrm{kg} /$ day).

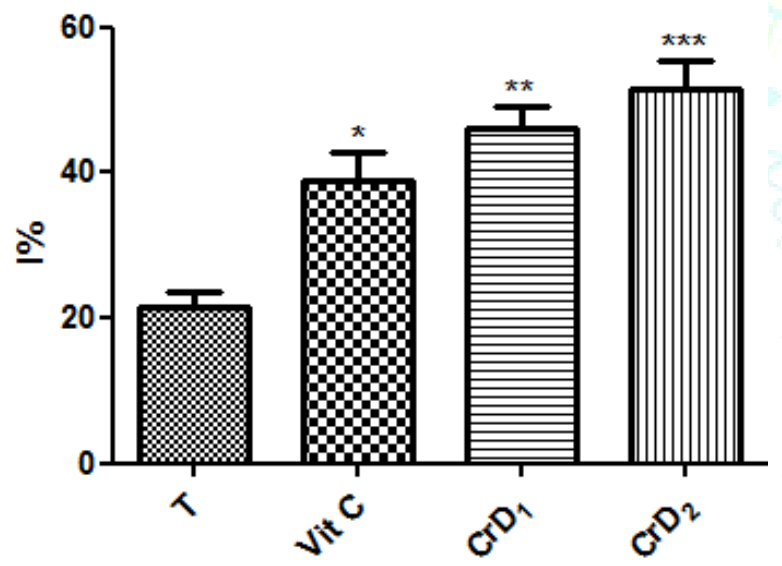

Figure 5: Antioxidant potential of $C$. calcitrapa in mice blood by using DPPH assay: $\mathrm{T}$ (control group treated with normal saline), Vit C (groups treated with a solution of Vit C $50 \mathrm{mg} /$ $\mathrm{kg}) \mathrm{CrD}_{1}, \mathrm{CrD}_{2}$ (groups treated with methanol extracts; 50 and $100 \mathrm{mg} / \mathrm{kg}$, respectively). Data are mean \pm SEM of $8-9$ animals in each group, comparisons are made with respect to the control group, ${ }^{*}: p \leq 0.05,{ }^{* *}: p \leq 0.01,{ }^{* * *}: p \leq 0.001$.

\section{CONCLUSION}

It is known that antioxidant activities increase proportionally with the flavonoids content. No significant correlation was recorded between flavonoids content of Centauria calcitrapa, DPPH scavenging and the reduction of $\beta$-carotene oxidation activities. However, the extracts showed a strong activity. From the in vitro results, the $\mathrm{CrE}$ seem to be of real and potential interest. To confirm the antioxidant potential of the $\mathrm{CrE}$, in vivo antioxidant properties were investigated. The analysis of results revealed that the $\mathrm{CrE}$ administration increased significantly the antihemolytic and free radical scavenging capacity of plasma. It can therefore be suggested that Centauria calcitrapa had potent antioxidant activities both in vitro and in vivo.

\section{Acknowledgement}

This work was supported by the Algerian Ministry of Higher Education and Scientific Research (MESRS) and by Algerian Agency for the Development of Research in Health (ANDRS).

\section{Conflict of Interest}

The authors have no conflicts of interest to declare.

\section{REFERENCES}

1. Pisoschi AM, Pop A. The role of antioxidants in the chemistry of oxidative stress: A review. Eur J Med Chem. 2015; 97:55-74.

2. Jones DP. Radical-free biology of oxidative stress. Am J Physio Cell Physiol. 2008; 295(4):C849-C868.

3. Pisoschi AM, Pop A, Cimpeanu C, Predoi G. Antioxidant capacity determination in plants and plant-derived products: a review. Oxi Med Cell Longev. 2016; 2016: 1-36.

4. Moon JK, Shibamoto T. Antioxidant assays for plant and food components. J Agric Food Chem. 2009; 11: 57(5):1655-1666.

5. Kooti W, Daraei N. A review of the antioxidant activity of celery (Apium graveolens L.). J Evid Based Complementary Altern Med. 2017; 22(4):1029-1034.

6. Miraj S, Kopaei R, Kiani S. Melissa officinalis L: A review study with an antioxidant prospective. J Evid Based Complementary Altern Med. 2017; 22(3):385-394.

7. Csupor D, Peták Z, Hohmann Medicinal perspective of Hungarian Centaurea species in the light of scientific evidence. J. Acta Pharm Hung. 2011; 81(2):63-75.

8. Domingos A, Cardoso PC, Xue ZT, Clemente A, Brodelius PE, Pais MS. Purification, cloning and autoproteolytic processing of an aspartic proteinase from Centaurea calcitrapa. Eur J Biochem. 2000; 267(23):6824-31.

9. Cappadone C, Mandrone M, Chiocchio I, Sanna C, Malucelli E, Bassi V, Picone G, Poli F. Antitumor potential and phytochemical profile ofplants from sardinia (italy), a hotspot for biodiversity in the mediterranean basin. Plants (Basel). 2019; 9(1):1-26.

10. Quezel P, Santa S. Nouvelle flore de l'Algerie et des régions desertiques méridionales. Paris: Centre National de la Recherche Scientifique; 1963. p 658-659.

11. Gay WI. Methods of animal experimentation (Vol-I). New York: Academic Press; 1965. p 32-191.

12. Trabsa H, Baghiani A, Boussoualim N, Krache I, Khennouf S, Charef N, Arrar L. Kinetics of inhibition of xanthine oxidase by Lycium arabicum and its protective effect against oxonateinduced hyperuricemia and renal dysfunction in mice. Trop J Pharm Res. 2015; 14(2):249-256.

13. Krache I, Boussoualim1N, Trabsa H, Ouhida S, Baghiani A, Arrar L. Antioxidant, antihemolytic, antihyperuricemic, antiinflammatory activity of algerian germander methanolic extract. Annual Research \& Review in Biology. 2018; 23(5):1-14.

14. Baghiani A, Djarmouni M, Boumerfeg S, Trabsa H, Charef N, Khennouf S, Arrar L. Xanthine oxidase inhibition and antioxidant effects of Peaganum harmala seed extracts. European J Med Plants. 2012; 2(1):42-56.

15. Baghiani A, Ameni D, Boumerfeg S, Adjadj M, Djarmouni M, Charef N, Khennouf S, Arrar L. Studies of antioxidants and xanthine oxidase inhibitory potentials of root and aerial parts of medicinal plant Capparis spinosa L. Am J Med Med Sci. 2012; 2:25-32.

16. Boumerfeg S, Baghiani A, Messaoudi D, Khennouf S, Arrar L. Antioxidant properties and xanthine oxidase inhibitory effects of Tamus communis L. Root Extracts. Phytother Res. 2009; 23:283288.

17. Baghiani A, Boussoualim N, Trabsa H, Aouachria S, Arrar L. In Vivo free radical scavenging, antihemolytic activity and antibacterial effects of Anchusa Azurea extracts. Int J Med Med Sci. 2016; 46:1114-1118.

18. Trabsa H, Boumerfeg S, Baghiani A, Boussoualim N, Krache I, Khennouf S, Arrar L. Int J Indig Med Plants. Anti-Haemolytic, antioxidant and xanthine oxidase inhibitory effect of Sedum sediforme shoot extracts. 2014; 47:1502-1510. 
19. Kumar S, Pandey AK. Chemistry and biological activities of flavonoids: An overview. 2013; 2013:1-16.

20. Denni M, Mammen D. A critical evaluation on the reliability of two aluminum chloride chelation methods for quantification of flavonoids. Food Chem. 2012; 135:1365-1368.

21. Huang D, Ou B, Prior RL. The chemistry behind antioxidant capacity assays, J Agric Food Chem. 2005; 53:1841-1856.

22. Yehye WA, Abdul Rahman N, Ariffin A, Abd Hamid SB, Alhadi AA, Kadir FA, Yaeghoobi M. Understanding the chemistry behind the antioxidant activities of butylated hydroxytoluene (BHT): A review. Eur J Med Chem. 2015; 101:295-312.

27. Pietta PG. Flavonoids as Antioxidants. J Nat Prod. 2000; 63:1035-1042.

28. Siddon AJ, Tormey CA. The chemical and laboratory investigation of hemolysis. Adv Clin Chem. 2019; 89:215-258.
23. Boumerfeg S, Baghiani A, Djarmouni M, Ameni D, Adjadj M, Belkhiri F, Charef N, Khennouf S et Arrar L. Inhibitory activity on xanthine oxidase and antioxidant properties of Teucrium polium L. extracts. Chin Med. 2011; 3:30-41.

24. Liu Y, Sun Y, Huang G. Preparation and antioxidant activities of important traditional plant polysaccharides. Int J Biol Macromol. 2018; 111: 780-786.

25. Noctor G, Lelarge-Trouverie $C$, Mhamdi A. The metabolomics of oxidative stress. Phytochemistry . 2015; 112:33-53.

26. Prasad KN, Chew LY,. Khoo HE, Yang B, Azlan A, Ismail A. Carotenoids and antioxidant capacities from Canarium odontophyllum Miq. Fruit. 2011; 124(4):1549-1555.

29. Sullivan SG, STERN A. Membrane protein changes induced by tert-butyl hydroperoxide in red blood Cells. Biochim Biophys Acta. 1984; 774:215-220.

30. Rajat G, Panchali D. A study on antioxidant properties of different bioactive compounds. J Drug Deliv Ther. 2014; 4(2):105-115. 